SCJR 11, no. 1 (2016): 1-2

\title{
Marvin R. Wilson Exploring Our Hebraic Heritage: A Christian Theology of Roots and Renewal
} (Grand Rapids, Michigan: William B. Eerdmans, 2014), xxviii + 304 pp.

\author{
JASON POLING \\ vicar@hildas.org \\ New Hope Community Church, Pikesville, MD 21208
}

Throughout his long and fruitful career, Marvin Wilson has worked tirelessly to help (and challenge) Christians to recognize and appreciate the Jewish roots of their faith. A professor of Old Testament at Gordon College, Wilson has produced a number of resources that are useful for the classroom as well as accessible to a popular audience. Readers of SCJR will likely be familiar with the PBS documentary Jews and Christians: People of Faith (2002) on which Wilson served as the chief scholar and study guide author. They may also be aware of Wilson's vital work alongside Rabbi James Rudin in facilitating the JewishEvangelical dialogues of the 1970s and 1980s and in editing the published papers from those meetings.

Exploring Our Hebraic Heritage serves as an apt successor to Wilson's 1989 volume Our Father Abraham: Jewish Roots of the Christian Faith (Eerdmans), which has gone through over two dozen printings. Indeed, Exploring Our Hebraic Heritage complements Our Father Abraham, and while a familiarity with the first volume is not necessary to appreciate the second, those who are familiar with it will no doubt be glad to have the other. There is some overlap between the two (and indeed some areas of repetition in this new volume), but as these books are likely to receive their greatest use in classrooms and adult learning over multiple sessions, this redundancy may be as much a strength as a weakness.

Wilson states that a main reason for writing this new book is "to bring to Christians of every stripe and background a renewal of perspective on various biblical themes" (p. xxiii). This is indeed a work of biblical theology which finds both its questions and its answers in the texts of the Tanakh and New Testament. Those accustomed to discussing religious matters with sacred texts ready in hand will find this volume a congenial companion.

Specialists will be disappointed to find that Wilson is more interested in raising important questions than he is in drawing upon the current state of academic discourse on them. He notes the contributions made by E. P. Sanders' Paul and Palestinian Judaism (1977) but does not mention (let alone engage) the vibrant development over the succeeding decades of new, fresh, and alternative perspec- 
tives on Paul. But in a work primarily aimed at students and literate lay readers, Wilson is probably wise to avoid getting too deep in the scholarly weeds.

Our Father Abraham, its title notwithstanding, gave scant attention to the patriarch himself. Exploring Our Hebraic Heritage devotes one of the book's five sections to him and his family. Wilson notes the "troubling" fact that "biblical" Christians may be in the church for a lifetime and yet remain largely uninformed about the biblical origins of their belief system" (p. 63). Therefore he discusses the character of Abraham as revealed in the Genesis narrative as well as the ways in which Abraham is understood in later Jewish and Christian biblical texts to constitute the communities formed by them.

Wilson's sixth chapter, "Thinking Theologically about Abraham," addresses themes of election, covenant, faith, and mission as they have been treated with respect to Abraham in both the Jewish and Christian traditions. Here, as in much of this book, Wilson provides ample fodder for discussion and further reflection, well-grounded in Scripture and informed by thoughtful Jewish and Christian voices. While the volume will no doubt be profitable to the individual reader, its greatest potential is to be realized by putting Wilson's work in dialogue with other studies-ideally, in an interfaith setting.

Indeed, a great advantage of this volume is that its content is deployed with such good intent. Wilson's voice is one of gentle insistence that for Christians to be faithful to their identity they must develop a profound appreciation of the Jewish sources of that identity, and of their neighbors who identify with that tradition. Throughout Exploring Our Hebraic Heritage, Wilson cites appreciatively the interpretive work of both ancient and contemporary Jewish commentators. The influence of Rabbi Abraham Joshua Heschel is especially evident, as it was in Our Father Abraham. Relations between Christians and Jews can only be improved by the kind of understanding that will enable Christians to develop the sincere affection for Judaism and Jewish people that is so evident in Wilson's work.

Like Our Father Abraham, this volume includes at the end of each chapter abundant study questions; some chapters have nearly 50 . While they will be most productive when employed by a skilled teacher or facilitator, these questions may still be useful in other settings as well. 